\title{
Phytochemistry, antibacterial and anticoagulase activities of Sida acuta against clinical isolates of Staphylococcus aureus
}

\author{
J. P. Essien ${ }^{1}$, B. S. Antia ${ }^{2}$ and G. A. Ebong * \\ ${ }^{1}$ Department of Microbiology, ${ }^{2}$ Department of Chemistry, University of Uyo, P. M. B. 1017 Uyo, NIGERIA \\ *Corresponding author. E-mail: goddyebong@yahoo.com
}

\begin{abstract}
The phytochemical, antibacterial and anticoagulase activities of Sida acuta against clinical isolates of Staphylococcus aureus were investigated. The phytochemistry of the plant leaves revealed that $S$. acuta is laden with antioxidative compounds with remarkable concentrations of saponins $(0.772 \mathrm{mg} / 100 \mathrm{~g})$, flavonoids $(0.112 \mathrm{mg} / 100 \mathrm{~g})$, alkaloids $(0.076 \mathrm{mg} / 100 \mathrm{~g})$ and tannins $(0.0541 \mathrm{mg} / 100 \mathrm{~g})$. Their presence conferred a strong bactericidal effect on Staphylococcus aureus SS-1VC, Staph. aureus SS-2VM, Staph. aureus SS-3SW, Staph aureus SS-4OM, Staph. aureus SS-5BC Staph. aureus SS-6AF and Staph. aureus SS-7DS isolated from vaginal candidiosis, vaginal mycosis, septic wound, otitis media, buccal cavity, athletes foot and diarrheic stool respectively. Majority of the bacterium strains screened were sensitive to aqueous and methanol extracts of $S$. acuta leaves. All the strains were inhibited by the aqueous extract, but more susceptible were strains SS-2VM isolated from vaginal mycoses and SS-3SW from septic wound, which recorded $25 \mathrm{~mm}$ and $24 \mathrm{~mm}$ diameter of inhibition zones respectively, after treatment with $8.0 \mathrm{mg} / \mathrm{ml}$ of the extract. However, much lower concentration $(0.5 \mathrm{mg} / \mathrm{ml})$ of the extract was required to halt coagulase activity in both strains. The methanol leaf extract exhibited similar but stronger antibacterial and anticoagulase activities against the clinical isolates of Staph. aureus. Marked antibacterial inhibitory effects were observed against most strains tested but SS-6AF and SS-7DS (which exhibited comparatively lower susceptibility), with majority of the strains losing their anticoagulase producing potential at concentrations as low as $0.5 \mathrm{mg} / \mathrm{ml}$ of alcoholic extract. The strong anticoagulase activity of S.acuta, and it's efficacy in inhibiting coagulase elaboration by Staph aureus especially Staph. aureus SS$3 \mathrm{SW}$ isolated from septic wound forms the basis of it's use in folk medicine for wound treatment.
\end{abstract}

Keywords: Phytochemistry, Antibacterial and Anticoagulase, Sida acuta,Staphylococcus aureus

\section{INTRODUCTION}

The usefulness of ethnobotanical surveys in drug discovery has been reviewed by many researchers (Benjamin, 1980; Sofowara, 1984; Odoemena et al., 1998; Dhawan, 1997; Essien et al., 1999; Ekpendu et al., 2000 and Essien and Akpan, 2004). Naturally occurring plant metabolites are useful sources of new biocidal compounds and some cases have served as leads for new compounds that have been characterized (Emele etal., 1997 and Essien and Akpan, 2004). However the search for new antimicrobial agents is a continuous exercise since target microorganisms often evolve new genetic variants (Agarwal et al., 1980, Locksley et al., 1982, Hughes and Datta, 1983 and Oyagade and Oguntoyinbo, 1997).

Development of resistance to antimicrobial agents by staphylococci is of major concern primarily because they are frequently associated with hospital and community acquired infections (Agarwal et al., 1980, Iroegbu et al., 1997 and Oyagade and Oguntoyinbo, 1997). Staphylococcus aureus is a ubiquitous microorganism. The young and debilitated individual are known to harbor this bacterium in their anterior nare (Ako-Nai et al., 1991) and other parts of the body (Famurewa and Sonntag, 1982). Staphylococcus aureus is a normal flora of some parts of the body such as the skin and nasal passage. It produces pustules, carbuncles and boils. It is also a frequent cause of burns and wound sepsis (Bulanda, 1989; and Oyagade and Oguntoyinbo, 1997). The virulence factors produced by human strains of Staph. aureus include a-toxins, protein A and coagulase. Other factors include the $y$-toxins which damages the tissue cells by its action as a phospholipase and lipase which catalyses the hydrolysis of fats and oils in the sebaceous secretion and blood plasma (Henning et al., 1979 and Oyagade and Oguntoyinbo, 1997). Apart from being associated with wound infections. Staph. aureus may contaminate food resulting in food poisoning which is a common cause of vomiting and diarrhea, and staphylococcal enterocolitis (Duguid et al., 1987).

Although the resistance of Staph. aureus to some antibiotics have been reported (Ako-Nai et al., 1991 and Oyagade et al., 1997), the bacterium is sensitive to many antibiotics (Duguid etal., 1987) and many traditional plant herbs and concoctions have been reported to have some 
medicinal value againstStaph. aureus associated ailments including septic wounds. Certain drug plants Centella asiatica and Aloe vera have been used for decades, both topically and internally, to enhance wound repair (MacKay and Miller,2003), and scientific studies are now beginning to validate efficacy and explore mechanisms of action for these drug plants. A typical example is the use of Sida acuta Burn F. (Malvaceae) as an astringent, cooling tonic and antipyretic herb. It is also a useful antimicrobial agent in nervous and urinary disorders, wound infection and diseases of the blood and bile (Peirce, 2000). However to the best of our knowledge a systematic study on the wound healing activity of $S$. acuta has not been undertaken and little is known about the efficacy or the extent of effectiveness of the plant leaf extracts against pathogenic microorganisms. In the present research we investigate the phytochemistry, antibacterial and anticoagulase activities of Sida acuta against clinical isolates of Staph. aureus.

\section{MATERIALS AND METHODS}

Phytochemistry of Sida acuta leaves : Preliminary phytochemical analysis of the petroleum ether extract of the plant leaves was carried out according to the methods outlined by Harborne (1984) and Evans (1998). Precisely, $500 \mathrm{~g}$ of the fine sample powder was successfully Soxhlet extracted with petroleum ether at room temperature ( $28 \pm$ $2{ }^{\circ} \mathrm{C}$ ). The extract was concentrated under pressure to yield $40 \mathrm{~g}$ of petroleum ether-extract. Screening for alkaloids was carried out with Mayer's, Dragendroff's and Picric acid reagents. Cardiac glycosides were detected by the KellerKilliani and Liberman's tests. The tannins were detected by the Ferric Chloride test, phlobatannins by hydrochloric acid test, saponins by the Frothing and Fehling's tests, flavonoids by Shinoda's test, sterol/triterpenes by sulphuric acid test and the anthraquinones by the Bontruger's test. The incidence of the antioxidants in the plant leaves was graded as being highly present $(+++)$, moderately present $(++)$, present in trace amount $(+)$ and absent (-).

Quantitative measurements of total crude sapogenins were by gravimetric method of Brain et al (1968), Alkaloid was quantified by the Harborne (1984), tannin by VanBurden and Robinson (1981) method and flavonoid by the method of Boham and Kocipai-Abyazan (1974), while the method of Obadoni and Ochuko (2001) was adopted for saponin determination.

Clinical isolates of staphylococcus aureus screened : Staphylococcus aureus SS-1VC originally isolated from vaginal candidiosis, Staph. aureus SS-2VM isolated from vaginal mycosis, Staph. aureus SS-3SW isolated from septic wound, Staph aureus SS-4OM isolated from otitis media, Staph. aureus SS-5BC isolated from buccal cavity,
Staph. aureus SS-6AF isolated from athletes foot and Staph. aureus SS-7DS isolated from diarrheic stool were obtained from the diagnostic laboratory of the University of Uyo Health Centre, Nigeria.

The isolates were streaked on selective media of blood agar, mannitol salt agar and staphylococcus medium 110. The inoculated plates were incubated at $37^{\circ} \mathrm{C}$ for 24 hours and the emerging colonies were purified by repeated subculturing and stocked in nutrient agar slants. Thereafter, the isolates were characterized according to the methods described by Cowan (1985) and Holt et al (1994) to ascertain their identities.

Preparation of leaf extracts for antibacterial and anticoagulase assays : Fresh Sida acuta plants were collected from the wild sources in Uyo, Nigeria and authenticated by a plant taxonomist. The leaves were separated, sundried and powdered for easy extraction. Precisely, $75 \mathrm{~g}$ of leaf powder was extracted with $700 \mathrm{ml}$ of $95 \%$ methanol in a Soxhlet apparatus at $60-75^{\circ} \mathrm{C}$. Extract was concentrated by evaporation using a rotary evaporator to obtain a pasty oily residue. The traditional extraction process in which $100 \mathrm{~g}$ of the leaf powder $(100 \mathrm{~g})$ was refluxed with $400 \mathrm{ml}$ of sterile double distilled water for 1 hour at $75^{\circ} \mathrm{C}$ (MacKay and Miller, 2003) was also adopted. It was cooled and then filtered. This was repeated in three trials. The extracts were pooled and evaporated using a lyophilizer to obtain $250 \mathrm{mg} / \mathrm{ml}$ extract concentration.

Aliquot of the methanol extract was adjusted using sterile distilled water, to match the concentration derived from the aqueous extract. Serially diluted antibacterial of the extracts were prepared to obtain graded concentrations for the assays.

Antibacterial assay of the leaf extracts : Antibacterial assay of the plant extracts was by the agar-punch-tube method (Stokes, 1975), a modification of the agar-diffusion method of Bauer etal. (1966) using Oxoid single sensitivity disc and Mueller-Hinton agar as the sensitivity test medium. The inoculum was standardized by streaking isolates of Staph. aureus from nutrient agar slants into mannitol salt agar and then incubated at $37^{\circ} \mathrm{C}$ for 24 hours. Distinct colonies of the emerging isolates were transferred into $5 \mathrm{ml}$ of nutrient broth and then incubated for 5 hours until its turbidity matched that of barium sulphate solution (Cheesbrough, 1985).

Using different concentrations of the methanol and aqueous extracts and by the agar-dilution method (Stokes, 1975) the antibacterial effect of graded concentration of extracts were determined for the 7 clinical strains of Staph. aureus screened. This procedure described by Cruickshank et al. (1982) has previously been used by Emele et al. (1997). 
Anticoagulase assay of the leaf extracts : Coagulase test is based on the ability of Staph. aureus to produce a protein product called coagulase. The test is usually carried out to differentiate the pathogenic Staph. aureus from other strains or species of staphylococci. Coagulase causes plasma to clot by converting fibrinogen to fibrin. Bound coagulase (clumping factor) which converts fibrinogen directly to fibrin without requiring a coagulase reacting factor can be detected by the clumping of bacterial cells in the rapid slide techniques.

To determine the anticoagulase potential of the leaf extracts, $0.2 \mathrm{ml}$ of broth cultures of each isolate was added to $0.5 \mathrm{ml}$ of the extract solution and incubated in a water bath at $37^{\circ} \mathrm{C}$. With known control, the test substrate was examined at intervals of 30 minutes for 4 hours (Cheesbrough, 1985 and Cowan, 1985). The effect of the different extracts concentrations on the coagulase activities of the Staph. aureus isolates was investigated using inhibited cultures and by the tube test.

For the tube test, free coagulase which converts fibrinogen to fibrin by activating a coagulase reacting factor present in plasma which is indicated by clotting was assayed. To achieve these three clean sterile test tubes were prepared; the first tube containing the inhibited test culture and medium $(0.8 \mathrm{ml}$ of 24 hour old broth culture), the second tube which served as the positive control contained the uninhibited broth culture while the third tube which served as the negative control had sterile broth. With the aid of sterile pipette $0.2 \mathrm{ml}$ of plasma was transferred into each test tube, mixed gently and incubated at $37^{\circ} \mathrm{C}$ for 1 hour. Observations were made to distinguish positive coagulase which showed clotting of tube content. The time or duration of clotting was determined with the aid of a stop watch (Quartz mechanical stop watch).

\section{RESULTS AND DISCUSSION}

Staphylococcus aureus has been one of the most successful of pathogenic bacteria due to its possession of aggressive factors and enzymes that can hydrolyze a wide range of substances (Volk et al., 1986). Among these factors is the production of coagulase, an enzyme-like protein that clots oxalated or citrated plasma in the presence of a factor contained in many sera. The serum factor reacts with coagulase to generate both esterase and clotting activities, in a manner similar to the activation of prothrombin to thrombin (Vassey and Mann, 1978). Coagulase may deposit fibrin on the surface of Staphylococcus aureus perhaps altering their ingestion or destruction by phagocytic cells (Volket al., 1986, Vassey and Mann, 1978). The present study has shown that both the aqueous and methanol leaf extracts of Sida acuta are laden with antioxidative compounds with remarkable concentrations of saponins $(0.772 \mathrm{mg} / 100 \mathrm{~g})$, flavonoids $(0.112 \mathrm{mg} / 100 \mathrm{~g})$, alkaloids $(0.076 \mathrm{mg} / 100 \mathrm{~g})$ and tannins
$(0.0541 \mathrm{mg} / 100 \mathrm{~g})$ (Table 1). These antioxidants have strong anticoagulase and antibacterial potentials. Its strong anticoagulase activity forms the basis for its use, and efficacy in inhibiting coagulase elaboration by the bacterium. However, the plant's anticoagulase activity varied with the bacterium strain and extracts concentration.

The aqueous extract (Table 2) delayed coagulase elaboration (plasma clotting within 30 minutes) byStaph. aureus strain SS-1VC isolated from vaginal cavity. Coagulase activity was noticed on the $32^{\text {nd }}$ minute, precisely 29 minutes after the activity was noticed (within 3 minutes) in the untreated culture of the test strain which served as control. Similarly, the coagulase activity of Staph. aureus strains SS-5BC isolated from the buccal cavity and SS-6AF from athlete's foot were also delayed for 8 minutes and 14 minutes respectively at the highest concentration $(8.0 \mathrm{mg} / \mathrm{ml})$ of extract applied. The delay in coagulase production by strains SS-1VC, SS-5BC and SS$6 \mathrm{AF}$ is an indication of the resistance of the isolates to the anticoagulase properties of the plant extract, and a pointer to the fact that the pathogens may not necessarily loss its virulence when treated with aqueous extract of Sida acuta despite their susceptibility to antibacterial properties of the plant. This implies that both attributes have different physiological determinants.

All the bacterial strains were inhibited by the aqueous extract, but more susceptible were strains SS-2VM isolated from vaginal mycoses and SS-3SW from septic wound, which recorded $25 \mathrm{~mm}$ and $24 \mathrm{~mm}$ diameter of inhibition zones respectively, after treatment with $8.0 \mathrm{mg} / \mathrm{ml}$ of the extract. Much lower concentration $(0.5 \mathrm{mg} / \mathrm{ml})$ of the extract was required to halt coagulase activity in both strains. Other isolates with disrupted coagulase activities were SS-4OM (isolated from otitis media) at $4.0 \mathrm{mg} / \mathrm{ml}$ and SS7DS (isolated from diarrheic stool) at $2.0 \mathrm{mg} / \mathrm{ml}$ of extract concentrations. Staphylococcus aureus strains SS-6AF and SS-7DS were the most resistant isolates to the antibacterial components of the aqueous extract.

The methanol leaf extract (Table 3) exhibited similar but stronger anticoagulase and antibacterial activities against the clinical isolates of Staph. aureus. Marked antibacterial inhibitory effects were observed against most strains tested but SS-6AF and SS-7DS (which exhibited comparatively lower susceptibility), with majority of the strains losing their anticoagulase producing potential at concentrations as low as $0.5 \mathrm{mg} / \mathrm{ml}$ of alcoholic extract. The stronger efficacy of the alcoholic extract against coagulase production and bacterial growth may be attributed to the more concentrated level of antioxidants in the methanol extract. This is suggestive that alcohol, as better solvent might have extracted more active components of the plant leaves than water. However in folk medicine $S$. acuta leaf extract are mostly applied in 
aqueous extract or free juice forms. Our findings have shown that better results may be achieved if alcoholic extract of the plant leaf is applied or even if used in dried powdery form. Similar observations have previously been reported by Emele et al (1997). This stems from the fact that the aqueous extract though with appreciable anticoagulase activity has limited antibacterial activity against many infectious strains of Staphylococcus aureus.

Our observation is in agreement with previous report that correlations between strains isolated from particular diseases and expression of particular virulence determinants, which suggest their role in a particular disease (Bergdoll, 1970) generally show that different

Table 1. Physicochemistry of Sida acuta leaves.

\begin{tabular}{|c|c|c|c|c|}
\hline Property & Test method & Observation & Remark & Concentration \\
\hline \multirow[t]{2}{*}{ Saponins } & i. Frothing test & Persistent foam & +++ & $0.772 \mathrm{mg} / 100 \mathrm{~g}$ \\
\hline & ii. Fehlings test & Brown ppt & ++ & \\
\hline Tannins & i. Ferric chloride test & Green ppt & ++ & $0.0541 \mathrm{mg} / 100 \mathrm{~g}$ \\
\hline Polyphenols & i.Ferric chloride test & No ppt & - & \\
\hline Alkaloids & $\begin{array}{l}\text { i. Dragendroffs test } \\
\text { ii. Mayer's test }\end{array}$ & Red ppt & +++ & $0.076 \mathrm{mg} / 100 \mathrm{~g}$ \\
\hline Flavonoids & i. Shinoda's test & & +++ & $0.112 \mathrm{mg} / 100 \mathrm{~g}$ \\
\hline Anthraquinones & i. Bontrugers test & & & \\
\hline Sterol/triterpenes & i. Sulphuric acid test & Pink ppt & + & \\
\hline \multirow[t]{2}{*}{ Cardiac glycosides } & $\begin{array}{l}\text { i. Keller- Killiani test } \\
\text { ii. Liberman's test }\end{array}$ & & + & \\
\hline & iii. Picric reagent & Redish brown ppt & + & \\
\hline Phlobatannins & Hydrochloric acid test & No ppt & - & \\
\hline
\end{tabular}

$+++=$ highly present,$++=$ moderately present,$+=$ present in trace amount, $-=$ absent

Table 2. Anticoagulase (duration of clotting; mins) and antibacterial activity (diameter of zone of inhibition; mm) of aqueous leaf extract of Sida acuta against different strains of Staphylococcus aureus.

\begin{tabular}{|c|c|c|c|c|c|c|c|c|}
\hline \multirow[b]{2}{*}{ Strain } & \multirow[b]{2}{*}{ Test } & \multirow[b]{2}{*}{ Control } & \multicolumn{6}{|c|}{ Concentration } \\
\hline & & & $0.25 \mathrm{mg} / \mathrm{ml}$ & $0.5 \mathrm{mg} / \mathrm{ml}$ & $1.0 \mathrm{mg} / \mathrm{ml}$ & $2.0 \mathrm{mg} / \mathrm{ml}$ & $4.0 \mathrm{mg} / \mathrm{ml}$ & $8.0 \mathrm{mg} / \mathrm{ml}$ \\
\hline \multirow{2}{*}{$\begin{array}{l}\text { SS- } \\
\text { 1VC }\end{array}$} & CTT & $3 \mathrm{mins}$ & 9 mins & $14 \mathrm{mins}$ & $21 \mathrm{mins}$ & $28 \mathrm{mins}$ & $32 \mathrm{mins}$ & $36 \mathrm{mins}$ \\
\hline & ABT & $0 \mathrm{~mm}$ & $5 \mathrm{~mm}$ & $7 \mathrm{~mm}$ & $14 \mathrm{~mm}$ & $16 \mathrm{~mm}$ & $17 \mathrm{~mm}$ & $19 \mathrm{~mm}$ \\
\hline \multirow{2}{*}{$\begin{array}{l}\text { SS- } \\
2 \text { VM }\end{array}$} & CTT & $9 \mathrm{mins}$ & $16 \mathrm{mins}$ & $\mathrm{NC}$ & $\mathrm{NC}$ & $\mathrm{NC}$ & $\mathrm{NC}$ & $\mathrm{NC}$ \\
\hline & ABT & $0 \mathrm{~mm}$ & $4 \mathrm{~mm}$ & $10 \mathrm{~mm}$ & $17 \mathrm{~mm}$ & $20 \mathrm{~mm}$ & $23 \mathrm{~mm}$ & $25 \mathrm{~mm}$ \\
\hline \multirow{2}{*}{$\begin{array}{l}\text { SS- } \\
\text { 3SW }\end{array}$} & CTT & $3 \mathrm{mins}$ & $6 \mathrm{mins}$ & $\mathrm{NC}$ & $\mathrm{NC}$ & $\mathrm{NC}$ & $\mathrm{NC}$ & $\mathrm{NC}$ \\
\hline & ABT & $0 \mathrm{~mm}$ & $7 \mathrm{~mm}$ & $9 \mathrm{~mm}$ & $14 \mathrm{~mm}$ & $18 \mathrm{~mm}$ & $21 \mathrm{~mm}$ & $24 \mathrm{~mm}$ \\
\hline \multirow{2}{*}{$\begin{array}{l}\text { SS- } \\
\text { 4OM }\end{array}$} & CTT & $15 \mathrm{mins}$ & $17 \mathrm{mins}$ & $17 \mathrm{mins}$ & $19 \mathrm{mins}$ & $21 \mathrm{mins}$ & $\mathrm{NC}$ & $\mathrm{NC}$ \\
\hline & ABT & $0 \mathrm{~mm}$ & $3 \mathrm{~mm}$ & $6 \mathrm{~mm}$ & $9 \mathrm{~mm}$ & $10 \mathrm{~mm}$ & $14 \mathrm{~mm}$ & $17 \mathrm{~mm}$ \\
\hline \multirow{2}{*}{$\begin{array}{l}\text { SS- } \\
\text { 5BC }\end{array}$} & CTT & $27 \operatorname{mins}$ & 33mins & 33mins & $33 \operatorname{mins}$ & 34mins & $34 \mathrm{mins}$ & $35 \mathrm{mins}$ \\
\hline & ABT & $0 \mathrm{~mm}$ & $5 \mathrm{~mm}$ & $6 \mathrm{~mm}$ & $9 \mathrm{~mm}$ & $11 \mathrm{~mm}$ & $16 \mathrm{~mm}$ & $18 \mathrm{~mm}$ \\
\hline \multirow{2}{*}{$\begin{array}{l}\text { SS- } \\
\text { 6AF }\end{array}$} & CTT & 30mins & 33 mins & $34 \mathrm{mins}$ & $36 \mathrm{mins}$ & 37mins & 39mins & $44 \mathrm{mins}$ \\
\hline & ABT & $0 \mathrm{~mm}$ & $3 \mathrm{~mm}$ & $5 \mathrm{~mm}$ & $8 \mathrm{~mm}$ & $12 \mathrm{~mm}$ & $16 \mathrm{~mm}$ & $17 \mathrm{~mm}$ \\
\hline \multirow{2}{*}{$\begin{array}{l}\text { SS- } \\
\text { 7DS }\end{array}$} & CTT & 4 mins & 8 mins & $11 \mathrm{mins}$ & $16 \mathrm{mins}$ & $\mathrm{NC}$ & $\mathrm{NC}$ & $\mathrm{NC}$ \\
\hline & ABT & $0 \mathrm{~mm}$ & $4 \mathrm{~mm}$ & $7 \mathrm{~mm}$ & $10 \mathrm{~mm}$ & $11 \mathrm{~mm}$ & $15 \mathrm{~mm}$ & $18 \mathrm{~mm}$ \\
\hline
\end{tabular}

$\mathrm{CTT}=$ coagulase tube test, $\mathrm{NC}=$ no coagulase, $\mathrm{ABT}=$ antibacterial test (zone of inhibition) 
Table 3. Anticoagulase(duration of clotting; $\mathrm{mns}$ ) and antibacterial activity (diameter of zone of inhibition; $\mathrm{mm}$ ) of methanolic leaf extract of Sidaacuta against different strains of Staphylococcus aureus.

\begin{tabular}{|c|c|c|c|c|c|c|c|c|}
\hline \multirow[b]{2}{*}{ Strain } & \multirow[b]{2}{*}{ Test } & \multirow[b]{2}{*}{ Control } & \multicolumn{6}{|c|}{ Concentration } \\
\hline & & & $0.25 \mathrm{mg} / \mathrm{ml}$ & $0.5 \mathrm{mg} / \mathrm{ml}$ & $1 \mathrm{mg} / \mathrm{ml}$ & $2.0 \mathrm{mg} / \mathrm{ml}$ & $4.0 \mathrm{mg} / \mathrm{ml}$ & $8.0 \mathrm{mg} / \mathrm{ml}$ \\
\hline \multirow[t]{2}{*}{ SS-1VC } & CTT & $3 \mathrm{mins}$ & 9 mins & $14 \mathrm{mins}$ & $40 \mathrm{mins}$ & $\mathrm{NC}$ & $\mathrm{NC}$ & $\mathrm{NC}$ \\
\hline & ABT & $0 \mathrm{~mm}$ & $9 \mathrm{~mm}$ & $14 \mathrm{~mm}$ & $19 \mathrm{~mm}$ & $22 \mathrm{~mm}$ & $25 \mathrm{~mm}$ & $27 \mathrm{~mm}$ \\
\hline \multirow[t]{2}{*}{ SS-2VM } & CTT & 9 mins & $26 \mathrm{mins}$ & $\mathrm{NC}$ & $\mathrm{NC}$ & $\mathrm{NC}$ & $\mathrm{NC}$ & $\mathrm{NC}$ \\
\hline & ABT & $0 \mathrm{~mm}$ & $7 \mathrm{~mm}$ & $14 \mathrm{~mm}$ & $19 \mathrm{~mm}$ & $26 \mathrm{~mm}$ & $29 \mathrm{~mm}$ & $28 \mathrm{~mm}$ \\
\hline \multirow[t]{2}{*}{ SS-3SW } & CTT & $3 \operatorname{mins}$ & $6 \mathrm{mins}$ & $\mathrm{NC}$ & $\mathrm{NC}$ & $\mathrm{NC}$ & $\mathrm{NC}$ & $\mathrm{NC}$ \\
\hline & ABT & $0 \mathrm{~mm}$ & $9 \mathrm{~mm}$ & $13 \mathrm{~mm}$ & $19 \mathrm{~mm}$ & $26 \mathrm{~mm}$ & $29 \mathrm{~mm}$ & $29 \mathrm{~mm}$ \\
\hline \multirow[t]{2}{*}{ SS-4OM } & CTT & $15 \mathrm{mins}$ & $27 \mathrm{mins}$ & $32 \mathrm{mins}$ & $\mathrm{NC}$ & $\mathrm{NC}$ & $\mathrm{NC}$ & $\mathrm{NC}$ \\
\hline & ABT & $0 \mathrm{~mm}$ & $6 \mathrm{~mm}$ & $9 \mathrm{~mm}$ & $11 \mathrm{~mm}$ & $13 \mathrm{~mm}$ & $16 \mathrm{~mm}$ & $19 \mathrm{~mm}$ \\
\hline \multirow[t]{2}{*}{ SS-5BC } & CTT & $31 \mathrm{mins}$ & $31 \mathrm{mins}$ & $\mathrm{NC}$ & $\mathrm{NC}$ & $\mathrm{NC}$ & $\mathrm{NC}$ & $\mathrm{NC}$ \\
\hline & ABT & $0 \mathrm{~mm}$ & $8 \mathrm{~mm}$ & $11 \mathrm{~mm}$ & $19 \mathrm{~mm}$ & $21 \mathrm{~mm}$ & $26 \mathrm{~mm}$ & $28 \mathrm{~mm}$ \\
\hline \multirow[t]{2}{*}{ SS-6AF } & CTT & $33 \mathrm{mins}$ & $23 \operatorname{mins}$ & $32 \mathrm{mins}$ & $\mathrm{NC}$ & $\mathrm{NC}$ & $\mathrm{NC}$ & $\mathrm{NC}$ \\
\hline & ABT & $0 \mathrm{~mm}$ & $6 \mathrm{~mm}$ & $8 \mathrm{~mm}$ & $12 \mathrm{~mm}$ & $17 \mathrm{~mm}$ & $19 \mathrm{~mm}$ & $18 \mathrm{~mm}$ \\
\hline \multirow[t]{2}{*}{ SS-7DS } & CTT & $4 \mathrm{mins}$ & $28 \operatorname{mins}$ & $\mathrm{NC}$ & $\mathrm{NC}$ & $\mathrm{NC}$ & $\mathrm{NC}$ & $\mathrm{NC}$ \\
\hline & ABT & $0 \mathrm{~mm}$ & $7 \mathrm{~mm}$ & $9 \mathrm{~mm}$ & $12 \mathrm{~mm}$ & $14 \mathrm{~mm}$ & $17 \mathrm{~mm}$ & $19 \mathrm{~mm}$ \\
\hline
\end{tabular}

$\mathrm{CTT}=$ coagulase tube test, $\mathrm{NC}=$ no coagulase $\mathrm{ABT}=$ antibacterial test (zone of inhibition)

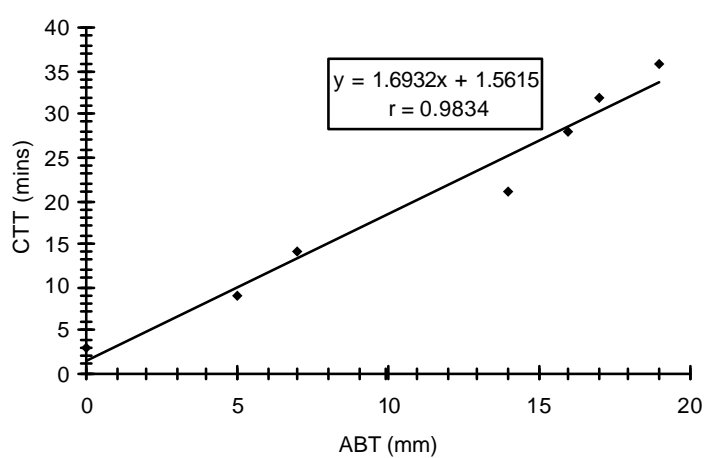

Fig. 1. Relationship between coagulase and antibacterial activities in Staph. aureus SS-1VC.

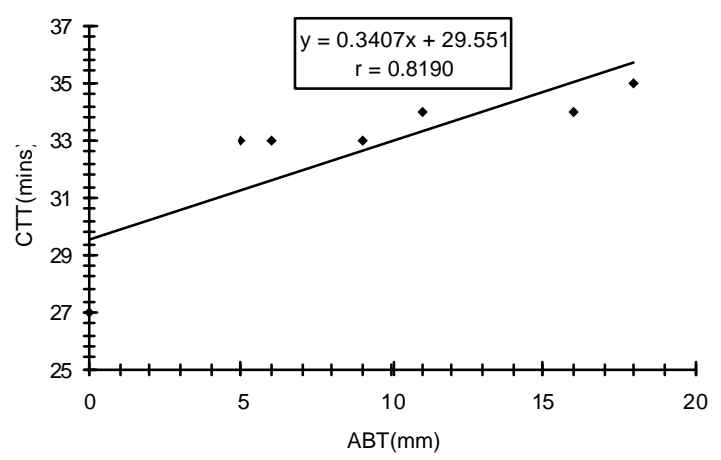

Fig. 2. Relationship between coagulase and antibacterial activities in Staph. aureus SS-5BC.

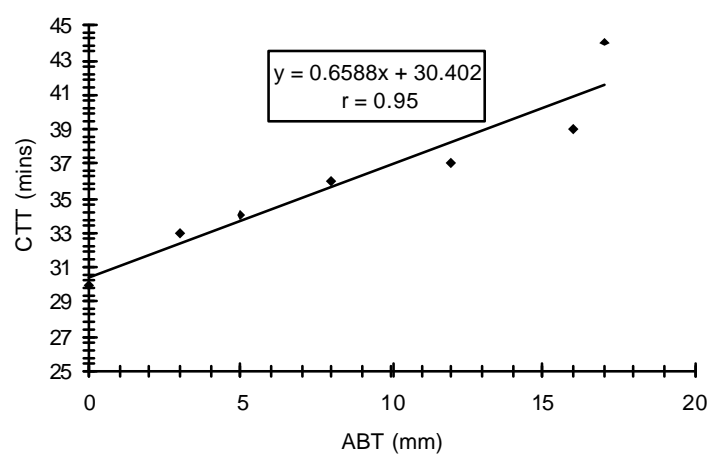

Fig. 3. Relationship between coagulase and antibacterial activities in Staph. aureus SS-6AF.

strains exhibit different levels of virulence. As a confirmation, analysis of the relationships between duration of clotting (coagulase activity) and zones of inhibition (antibacterial activity) in resistant strains SS1VC (Fig. 1), SS-5BC (Fig. 2) and SS-6AF (Fig. 3) and Staph. aureus treated with the aqueous extract revealed significant positive relations between the two attributes. This implies that coagulase production is necessary for the growth of the etiological agent and that resistant strains of Staph aureus can effectively elaborate coagulase under inhibitory conditions. Therefore controlling the rate of either using $S$. acuta leaf extract may retard the pathogenicity of Staph aureus. However, halting both the coagulase and cells multiplication would enhance healing of wound sepsis caused by Staph. aureus. 


\section{Conclusion}

Wound contraction is the process of mobilizing healthy skin surrounding the wound to cover the denuded area (Shanbhag et al., 2006). The centripetal movement of the wound margin is believed to be due to activity of myofibroblast (Gabbaiani et al., 1976). Like other wound healing botanicals such as Kaempferia galanga, the anticoagulase and antibacterial activities of Sida acuta against wound sepsis inducing strain of Staph. aureus would enhanced the contractile property of myofibroblast or increased the number of myofibroblasts recruited into the wound area. Our research have shown that its potential to enhance the property of myofibroblast via reduced anticoagulase and enhanced antibacterial activities of wound sepsis causing Staph. aureus varies with etiological strain, extract concentrations, nature of wound and the method in which the extracts were derived. Alcoholic extract exhibited stronger efficiency than aqueous extract usually used by traditional wound healers in folk medicine. These findings may reflect the different modes of action of the unrefined antioxidative components of the plant leaf.

In recent years oxidative stress has been implicated in a variety of degenerative process and diseases. These include acute and chronic inflammatory condition such as wound healing (Maiere and Chan, 2002). Wound healing plants are known to possess antioxidants especially flavonoids which are responsible for free radical scavenging activity required for wound healing (Devipriya and Shyamaladevi, 1999). Phytochemical screening revealed the presence of remarkable concentration of flavonoids in Sida acuta. This plus the presence of other antioxidants, such as saponins, tannins and alkaloids could be the reason for the strong anticoagulase and antibacterial potentials, and pro-healing activity of $S$. acuta.

\section{REFERENCES}

Agarwal, S. K., Khan, A. M., Srivastava, A.M., Mahrota, R. and Mahrota, R. M. L. (1980). Staphylococcal wound infection in surgical ward at Lucknow. Indian Journal of Medical Research 72: 807-813.

Ako-Nai, A. K., Ogunniyi, A. D., Lamikanra, A. and Torimiro, S. E. A. (1991). A survey of nasal carriage of Staphylococcus aureus in a neonatal ward in Ile- Ife, Nigeria. Annals of Tropical Paediatrics 11: 41-45.

Bauer, A. W., Kirby, W., Sherris, J. C. and Turck, M. (1966). Antibiotic susceptibility testing by a standardized single disc method. American Journal of Clinical Pathology 45: 493-496.

Benjamin, T. V. (1980). An approach to the study of medicinal plants with reference to Mitracarnus scrabra.Journal of African Medicinal Plants 3: 135-139.

Bergdoll, M S. (1970). Enterotxins In: Microbial Toxins, Vol. 3 (T. C. Montie, S. Kadia and S. J. Aji eds). Academic Press New York 265p.
Boham, B. A. and Kocipai- Abyazan, R. (1974). Flavonoids and condensed tannins from leaves of Hawaiian vaccinium vaticulatum and V. calycinium. Pacific Science 48: 458 463.

Brain, K. R., Fazil, F., Hardman, R. and Wood, A. B. (1968) The rapid quantitative determination of $\mathrm{C} 25$ epimeric steroidal sapogenins in plants. Phytochemistry 7:1815 - 1823.

Bulanda, M., Gruszka, M. and Heezko, B. (1989) Effect of mupitocin on nasal carriage of Staphylococcus aureus. Journal of Hospital Infection 19: 113-122.

Cheesbrough, A. (1985). Antimicrobial sensitivity testing, In: Medical Laboratory Manual for Tropical Countries Vol. II, Microbiology, $1^{\text {s }}$ Edition, Butterworths pp 196-205.

Cowan, S. T. (1985). Cowan and Steel's Manual for the Identification of Medical Bacteria, Cambridge University Press, London and New York pp 54-120.

Cruickshank, R., Duguid, J. P., Marmion, B. P. and Swain, R. H. A (1982). Tests for sensitivity to antimicrobial agents. In: Medical Microbiology vol. 2: The Practice of Medical Microbiolology. $2^{\text {nd }}$ edition. Churchill Livingstone, pp 190 208.

Devipriya, S. and Shyamaladevi, C. S. (1999). Protective effect of quercetin induced cell injury in the kidney. Indian Journal of Pharmacology 1:422-424.

Dhawan, B. N. (1997). Bioassay of plant products and development of new drugs. 'The International Workshop on Cultivation, Processing and Conservation of Medicinal and Aromatic Plants' $18^{\text {th }}-20^{\text {th }}$ March 2007, Abuja.

Duguid, J. P., Marmion, B. P. and Swain, R. H. A. (1987). Mackie and McCartney Medical Microbiology, Vol. 1: Microbial Infections $13^{\text {th }}$ edition English Language Books Society pp 235- 241.

Ekpendu, T. O. E., Anyogo, P., Ityough, D. and Akpa, F. (2000). Nigerian ethnomedicine and medicinal plant flora: The Benue experience - Part 3 Nigerian Journal of Natural Products and Medicine 4: 13 - 2.

Essien, J. P., Igiran, I. E. Udosen, E. D. and Asuquo, J. E. (1999). Chemical analysis and antibacterial activity of seed extract of ripe and unripe paw paw (Carica papaya) fruit. Journal of Science, Engineering and Technology. Nigeria 6(2) $1779-1784$.

Essien, J. P. and Akpan, E. M. (2004). Antifungal activity of ethanolic leaf extract of Eucalyptus camaldulensis against ringworm pathogens. Global Journal of Pure and Applied Sciences, Nigeria 10 (1): $37-41$.

Emele, F. E., Agbonlahor, D. E. and Emokpare, C. I. (1997). Antimicrobial activity of Euphorbia hirta leaves collected from two geographically dissimilar regions of Nigeria. Nigerian Journal of Microbiology 11: 5-10.

Evans, W. C. (1998). Trease and Evans Pharmacognosy, Bailliere Tindall, London.

Famurewa, O. and Sonntag, H. G. (1982). Cell membrane structures as factors of pathogenicity in staphylococci. First communication: Biochemical and physiological differentiation of staphylococci. Zentralblatt fur Bakteriologie und Hygiene Abteilung 1 Original A 251:463-464.

Gabbaiani, G., Harschel, B. J. and Ryan, G.B. (1976). Granulation tissue as a contractile organ. Journal of Experimental Medicine 135: 719 . 
Harborne, J. B. (1984). Phytochemical Methods, $2^{\text {nd }}$ Edition, Chapman and Hall, London pp20-22.

Henning, C. H., Ilborgh, U., Lindrall, K., Marquauson, O., Sellers, J., Walin, S. and Ransjo, U. (1979). Comparison of Staphylococcus aureus carriage and skin infection rates in hospital and office employee. Journal of Hygiene 83: 437 444.

Holt, J. G., Krieg, N. P., Sneath, P. A. A., Staley, J. and Williams, S. T. (1994). Bergey's Manual of Determinative Bacteriology, $9^{\text {th }}$ edn. Williams and Wilkins Publishers, Baltimore 787p

Hughes, V.M. and Datta, N. (1983). Conjugative plasmids in bacteria 'pre-antibiotic era' Nature 320.

Iroegbu, C. U., Ejimofor, O. D. Okpala, C. N., Otti, N and Owuna, R. (1997). Staphylococcus aureus surveillance in Nsukka, Nigeria: II. Antibiotic sensitivity patterns of nasal isolates. Nigerian Journal of Microbiology 11: 15-19.

Locksley, R. M., Cohen, M. L., Quinn, T. C., Tompkins, L. S., Coyle, M. B., Kirihara, J. M. and Counts, G. W. (1982). Multiple antibiotic-resistant Staphylococcus aureus: Introducton, transmission and evolution of nosocomial infection. Annals of International Medicine 97: 317-324.

Maiere, C.M. and Chan, P.H. (2002). Role of superoxide dismutase in oxidative damage and neurodegenerative disorders. Neuroscientist 8: 323-324.

Mackay, D and Miller, A. L. (2003). Nutritional support for wound healing Alternative Medicine Review 8 (4): 359-377.

Obadoni, B. O. and Ochuko, P. O. (2001). Phytochemical studies and comparative efficacy of the crude extracts of some homeostatic plants in Edo and Delta States of Nigeria, Global Journal of Pure and Applied Sciences, 8b: 203 - 208.
Odoemena, C. S., Akpabio, K. E. and Nneji, C. P. (1998). Antibacterial activity of the essential oils from four selected varieties of Capsicum annuum. Nigeria Journal of Natural Products and Medicine 2: 49-50.

Oyagade, J. O. and Oguntoyinbo, F. A. (1997). Incidence of antibiotic resistant Staphylococcus aureus strains among isolates from environmental and clinical sources. Nigerian Journal of Microbiology 11: 20-24.

Peirce, J. (2000). A Brief Introduction to Taxonomy and Nomenclature: Declared Plant Handbook - Weed Science. Weed Science Home India, pp 11 - 12.

Shanbhag, T. V., Chandrakala, S., Sachidananda, A., Laxminarayana, K., Smita, S. and Ganesh, S. (2006). Wound healing activity of alcoholic extract of Kaempferia galangal in Wistar rats. Indian Journal of Physiology and Pharmacology 50(4): 384-390.

Stokes, E. J. (1975). Clinical Bacteriology $4^{\text {th }}$ edition Edward Arnold Publishers pp 203-261.

Sofowora, A. (1984). Medicinal Plants and Traditional Medicine in Africa $1^{\text {st }}$ edition John Wiley and Sons Publishers, New York pp 208-213.

Vassey, M. P. and Mann, J I (1978). Female sex hormones and thrombosis: Epidemiology aspects. British Medical Bulletin 34:157-162.

Van-Burden, T. P. and Robinson, W. C. (1981). Formation of complexes between protein and tannin acid. Journal of Agriculture and Food Chemistry, 1:77- 78.

Volk, W. A., Benjamin, D. C., Kadner, R. J. and Parsons, J. J. (1986). Essentials of Medical Microbiology $3^{\text {rd }}$ Edition J. B. Lippino Cott Company, Philadelphia pp 373-381. 